\title{
STUDY OF HYDROCARBON-SHALE INTERACTION
}

Progress Report No. 4, April 1-June 30, 1977

\author{
Paul D. Schettler
}

Work Performed Under Contract No. EY-76-S-05-5197

Juniata College

Huntingdon, Pennsylvania 16652

\section{U. S. DEPARTMENT OF ENERGY}




\section{DISCLAIMER}

This report was prepared as an account of work sponsored by an agency of the United States Government. Neither the United States Government nor any agency Thereof, nor any of their employees, makes any warranty, express or implied, or assumes any legal liability or responsibility for the accuracy, completeness, or usefulness of any information, apparatus, product, or process disclosed, or represents that its use would not infringe privately owned rights. Reference herein to any specific commercial product, process, or service by trade name, trademark, manufacturer, or otherwise does not necessarily constitute or imply its endorsement, recommendation, or favoring by the United States Government or any agency thereof. The views and opinions of authors expressed herein do not necessarily state or reflect those of the United States Government or any agency thereof. 


\section{DISCLAIMER}

Portions of this document may be illegible in electronic image products. Images are produced from the best available original document. 


\section{NOTICE}

This report was prepared as an account of work sponsored by the United States Government. Neither the United States nor the United States Department of Energy, nor any of their employees, nor any of their contractors, subcontractors, or their employees, makes any warranty, express or implied, or assumes any legal liability or responsibility for the accuracy, completeness or usefulness of any information, apparatus, product or process disclosed, or represents that its use would not infringe privately owned rights.

This report has been reproduced directly from the best available copy.

Available from the National Technical Information Service, U. S. Department of Commerce, Springfield, Virginia 22161.

Price: Paper Copy $\$ 4.50$

Microfiche $\$ 3.00$ 
ORO-5197-4

Distribution Category UC-91

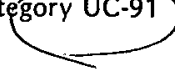

\title{
STUDY OF HYDROCARBON - SHALE INTERACTION
}

\section{PROGRESS REPORT \#4}

\author{
April 1-June 30, 1977 \\ April 1-June 30, 1977 \\ Paul D. Schettler, Principal Investigator \\ Juniata College \\ Iluntingdon, Pennsylvania 16652
}

This report was prepared as an account of work sponsored by the United States Govemment. Neither the United States nor the United States Department of Energy, nor any of their employees, nor any of their contractors, subcontractors, or their employees, makes any warranty, express or implied, or assumes any legal liability or responsibility for the accuracy, completeness or usefulness of any information, apparatus, product or pruces disclused, or represents that its use would not infringe privately owned rights.

Prepared for Energy Research and Development Administration under Contract No. Ey-76-S-05-5197 
TABIF: OPE CONTFNTS

ABSTRACT . . . . . . . . . . . . . . . . . . . .

A, WORK SCHEDULE AND ANTICIPATED WORK SCHEDULE

OF PERSONNEL INVOLVED. . . . . . . . . . . . . . . . . . . . . . . .

B. CORRELATION OF METHANE CONTENT WITH LITHOLOGY,

WELI $\# 20403$ LINCOLN COUNTY, WEST VIRGINIA. . . . . . . . . . . . . . B1-B9

C. STATUS AND DETAILED PLANS FOR CONSTRUCTION OF BET/ISOTHERM SYSTEMS. . . . . . . . . . . . . . . . . . . . . C1-C4

D. DESIGN AND CONSTRUCTION OF SKINNER MAGNA LATCH VALVE TO NOVA DIGITAL I/O INTERFACE. . . . . . . . . . . . . . . . . . . Dl-D3

E. THE RELATIONSHIP OF THERMODYNAMIC AND KINETIC PARAMETERS TO WELL PRODUCTION IN DEVONIAN SHALE . . . . . . . . . . . . . E E1-E15

F. 'Hllavli. . . . . . . . . . . . . . . . . . . . . E16

G. FINANCIAL DATA . . . . . . . . . . . . . . . . . . E E 
ABSTRACT

This report covers work on the Hydrocarbon-Shale Interaction at Juniata College from 1 April to 30 June 1977 on Contract No. DY-76-S-05-5197. Before 22 May, Paul Schettler and Eric Jensen were involved in the work. Since 22 May, seven investigators have been involved on a rotating schedule that has 2-3 people in the laboratory at any given time (Section A). All personnel utilized have a strong background in Laboratory work; one week (22 May-27 May) was spent orienting them to the details of this project. Since that time, 84 measurements (diffusion constants, BET's, or ice temperature isotherm) have been performed on 17 core samples of the Lincoln County 非20403 we1l (Section E). In addition, we have effected outgassing analyses on 129 samples for $\mathrm{CH}_{4}, \mathrm{C}_{2} \mathrm{H}_{6}, \mathrm{C}_{3} \mathrm{H}_{8}, \mathrm{O}_{2}, \mathrm{~N}_{2}$, and $\mathrm{CO}_{2}$ (Section $\left.B\right)$. Finally, we have completed the first step toward the construction of an automated diffusion constant/isotherm system (Sections $C$ and D). 
SECTION A

WORK SCHEDULES OF PERSONNEL

23 May-30 June 1977

(1 July-2 Sept 1977 tentative)

Weeks

\begin{tabular}{rrrrrrrrrrrrrrr}
1 & 2 & 3 & 4 & 5 & 6 & 7 & 8 & 9 & 10 & 11 & 12 & 13 & 14 & 15 \\
\hline
\end{tabular}

D. Wampler $X \quad X \quad X \quad X$

$\begin{array}{lllll}X & \mathrm{X} & \mathrm{X} & \mathrm{X} & \mathrm{X}\end{array}$

D. Mitchel1

$\begin{array}{lllllllll}X & X & X & X & X & X & X & X\end{array}$

P. Sipling

$\begin{array}{lllll}X & X & X & X & X\end{array}$

$\mathrm{X} \quad \mathrm{X} \quad \mathrm{X}$

$\mathrm{X} \quad \mathrm{X}$

$\begin{array}{lllllllllll}\text { M. Linton } & X & X & X & X & X & X & X & X & X & X\end{array}$

$\begin{array}{llllllllllllllllllllllllll}S & X & X & X & X & X & X & X & X & X & X\end{array}$

$\begin{array}{lllllllllll}E \text {. Boden } & X & X & X & X & X & X & X & X & X & X\end{array}$

$\begin{array}{llllllllllllll}\text { J. Nelson } & X & X & X & X & X & X & X & X & X & X\end{array}$

Note: Each day is split into shifts so that the BET/diffusion apparatus is manned about $13 \mathrm{hrs} /$ day in a manner so that no overtime is required. Work is further scheduled so that necessary degassing (and other tasks requiring down time) is accomplished over meal times and at night. Shifts are arranged so that two persons are in the laboratory at all times for safety. 
CORRELATION OF METHANE CONTENT WITH LITHOLOGY

WELL 非20403 LINCOLN COUNTY, WEST VIRGINIA

Philip J. Sipling

Gas chromatograph analyses for methane, ethane, propane, oxygen, nitrogen, carbon dioxide, and hydrogen sulfide have been completed for al1 canned cores supplied to us which were taken from We11 非20403, Lincoln County, West Virginia. This discussion will summarize the correlations between the percentage of methane gas (methane/total gas) in the canned samples and the type of shale which liberated this gas. Because only a few cans have been opened, the rock descriptions used will be those made at the well site. See Table I, page B4.

The terms used to refer to the Iithologic units are: Upper Gray Shale; Upper Brown Shàle; Middle Gray Shale; Middle Brown Shale; Lower Gray Shale; Lower Brown Shale. These are listed in order from youngest to oldest, $\underline{i} . \underline{e}$. , in order of increasing depth. They will be discussed in the same order.

The first section of core from Wel1 非 20403 consists of Upper Gray Shale beginning with the first sample at 2736 feet and continuing to the base of this unit at a log depth of approximately 2950 feet. Within this section there is a definite correlation between percentage methane in the gas and the degree of lightness or darkness of the shale, $\underline{i} . \underline{e} .$, the amount of organic material. The methane content of the gas varies from zero to $6 \%$ for the gray-green, medium gray, medium dark gray, and dark gray silty shales. Most analyses indicate less than $2 \%$ methane. The dark gray and very dark gray shales range up to $18 \%$ methane with 8 of 14 samples having greater than $10 \%$ methane. The silty shales consistent ly have low hydrocarbon contents.

The Upper Brown Shale is approximately 50 teet thick, extending from a depth of about 2950 feet to 3000 feet. A11 analyses indicate less than 10\% methane with 6 of 10 having less than 3\% methane. Although the Upper Brown Shale untes are renerally dark slides devoid of silt, they are relatively deficient in methane when compared to the dark shales of the Upper Gray Shale. 
The most extensive part of the core lies in the Middle Gray Shale extending from a depth of approximately 3000 feet to 3400 feet. Most of the shale in this section is medium gray, dark gray, and very dark gray. There were 79 analyses run on the samples from this section of the core. For 66 of the 79 analyses, the methane content is less than $10 \%$. Those samples with the percent methane greater than $10 \%$ were dark gray, very dark gray, and black shales. One sample, $3366^{\prime} 2-4^{\prime \prime}$, which consisted solely of black shale, had a methane content of $50 \%$. The Middle Brown Shale lies at a depth of 3400 to 3650 feet. For 35 of the samples trom this section of core the description is black shàle. The mechane content for 27 of the 35 black shale samples is greater than $10 \%$ methane. As a unit, the Middle Brown Shale is very high in methane content.

'the Lower Gray Shale extends from a depth of approximately 3650 feet to 3950 feet. Down to a depth of 3850 feet, the rock is primarily a blue gray shale. Except for two samples, the percent methane is less than four. There are six black shale samples in the lower 100 feet of this part of the section. Four analyses indicated less than $4 \%$ methane; the other two analyses indicated $29 \%$.

The lowest section of the core consists of the Lower Brown Shale extending from a depth of approximately 3950 feet to the last sample at 4026 feet. The rocks of this section of the core consist almost entirely of black and dark gray shales. Sixteen analyses were run on samples from this portion of the section. The methane content for 11 of the 16 samples was greater than $10 \%$ methane with a maximum of $36 \%$ methane. This section of the core contains a relatively high amount of methane.

The highest percentage of methane comprising the gas in the cans is associated with black shales; however, not all black shales yield methane. Generally the smallest amounts of methane are associated with the silty shales. Very dark gray and dark gray shales generally yield higher percentages of methane than medium gray and blue gray shales. 
This discussion is based upon the data presented here, along with the data irom cans analyzed a year ago (1). The procedures are the same as before except that pressures were measured with a mercury manometer to $1 \mathrm{~mm}$ (permitting better accuracy and positive and negative measurement. The pressures given are gauge; the barometric pressure was $743.4 \mathrm{~mm}$ (corrected) and the temperature was $22.5^{\circ} \pm 2^{\circ}$ during the time of measurement. Some pressure measurements are missing because of technical difficulties; these cans were approximately atmospheric in pressure.

\section{BIBLIOGRAPHY}

1. Hoeflich, L., Jensen, E., Wampler, D., Schettler, P., "Analysis of Hydrocarbon Gases from Cores of We11 \#20403, Lincoln County, West Virginia," in ORO-5197-1, Study of Hydrocarbon-Shale Interation, Progress Report 非1, prepared by Juniata College under Contract No. E(40-1)-5197 for USERDA, 1976. 
TABLE I

GAS ANALYSIS AS A FUNCTION OF DEPTH, WELL 非20403

\begin{tabular}{|c|c|c|c|c|c|c|c|c|c|}
\hline $\begin{array}{l}\text { Depth of } \\
\text { Sample }\end{array}$ & $\begin{array}{l}\text { Weight of } \\
\text { Shale (g) }\end{array}$ & & $\left(i n^{2}\right)$ & $\%$ & $\mathrm{C}_{2}^{\%} \mathrm{H}_{6}$ & $\mathrm{C}_{3}^{\%} \mathrm{H}_{8}$ & $\begin{array}{c}\% \\
\mathrm{CO}_{2}\end{array}$ & $\begin{array}{l}\% \\
\mathrm{O}_{2}\end{array}$ & $\begin{array}{l}\% \\
N_{2}\end{array}$ \\
\hline $2726^{\prime} 2^{\prime \prime}$ & 1109.4 & & & 0 & 0 & 0 & 0 & 20.0 & 80.0 \\
\hline $2736^{\prime} 2^{\prime \prime}$ & 1074.4 & & & 1.69 & 0 & 0 & 0 & 15.8 & 82.0 \\
\hline $2746^{\prime} 2^{\prime \prime}$ & 616.5 & - & .26 & 0.29 & 0 & 0 & 3.36 & 15.4 & 80.9 \\
\hline $2756^{\prime} 2^{\prime \prime}$ & 799.6 & - & .46 & 3.11 & 1.0 & 0 & 0 & 7.4 & 83.5 \\
\hline $2766^{\prime} 2^{\prime \prime}$ & 1016.8 & - & .74 & 6.02 & 1.4 & 0 & 5.3 & 2.2 & 85.1 \\
\hline $2776^{\prime} 2^{\prime \prime}$ & 790.6 & $<$ & .25 & 0.90 & 0 & 0 & 4.5 & 10.9 & 83.6 \\
\hline $2786^{\prime} 2^{\prime \prime}$ & 920.9 & - & .40 & 4.06 & 1.5 & 0 & 2.9 & 5.6 & $86: 0$ \\
\hline $2796^{\prime} 2^{\prime \prime}$ & 1146.9 & - & .34 & 0.37 & 0 & 0 & 4.7 & 13.1 & 81.8 \\
\hline $2806^{\prime} 2^{\prime \prime}$ & 1319.0 & & & 1.17 & 0 & 0 & 7.0 & 1.8 & 90.0 \\
\hline $2816^{\prime} 2^{\prime \prime}$ & 994.8 & & & 0.69 & 0 & 0 & 5.1 & 9.8 & 84.4 \\
\hline $2826^{\prime} 2^{\prime \prime}$ & 941.7 & - & .20 & 1.40 & 0.8 & 0 & 0 & 12.5 & 85.3 \\
\hline $2836^{\prime} 2^{\prime \prime}$ & 962.2 & - & .15 & 2.64 & 0.8 & 0 & 0 & 14.1 & 82.4 \\
\hline $2846^{\prime} 2^{\prime \prime}$ & 980.5 & $<$ & .25 & 1.69 & 0 & 0 & 3.7 & y. & 88.7 \\
\hline $2856^{\prime} 2^{\prime \prime}$ & 1055.3 & & .04 & 4.96 & 1.8 & 0 & 3.5 & 8.2 & 81.6 \\
\hline $2866^{\prime} 2^{\prime \prime}$ & 1164.8 & & .10 & 3.58 & 1.2 & 0 & 5.0 & 58 & 84.4 \\
\hline $2876^{\prime} 2^{\prime \prime}$ & 933.6 & & .05 & 2.30 & 0.8 & $u$ & 0 & 15.6 & 81.3 \\
\hline $2886^{\prime} 2^{\prime \prime}$ & 1005.8 & & 1.0 & 12.48 & 3.1 & 0.7 & 6.9 & 6.7 & 70.2 \\
\hline $2896^{\prime} 2^{\prime \prime}$ & 968.9 & & 0 & 4.28 & 2.8 & 1.4 & 7.7 & 3.8 & 80.1 \\
\hline $2906^{\prime} 2^{\prime \prime}$ & 826.6 & & & 4.71 & 2.3 & 1.0 & 7.7 & 0.7 & 83.6 \\
\hline $2916 ' 7 . "$ & 1504.8 & & & 11.72 & 3.0 & 1.7 & 6.9 & $n$ & 75.8 \\
\hline $2926^{\prime} 2^{\prime \prime}$ & 1256.8 & - & .38 & 9.61 & 2.8 & 0 & 5.2 & 2.4 & 80.0 \\
\hline $2936^{\prime} 2^{\prime \prime}$ & 1658.5 & & .22 & 1.78 & 0 & 0 & 6.5 & 10.9 & 80.8 \\
\hline $2946^{\prime} 2^{\prime \prime}$ & 1315.6 & - & .09 & 10.53 & 2.9 & 1.3 & 7.7 & 0.5 & 77.0 \\
\hline $2956^{\prime} 2^{\prime \prime}$ & 991.6 & & .03 & 1.19 & 0 & 0 & 0 & 19.4 & 79.4 \\
\hline
\end{tabular}




\begin{tabular}{|c|c|c|c|c|c|c|c|c|}
\hline $2966^{\prime} 2^{\prime \prime}$ & 1103.5 & $<0.01$ & 0.65 & 0 & 0 & 0 & 21.1 & 78.3 \\
\hline 2976 '2" & 1086.8 & .06 & 0.26 & 0 & 0 & 0 & 21.2 & 78.6 \\
\hline $2986^{\prime} 2^{\prime \prime}$ & 1285.4 & & 0.42 & 0 & 0 & 0 & 21.3 & 78.3 \\
\hline $2996^{\prime} 2^{\prime \prime}$ & 1206.2 & & 0.07 & 2.0 & 0 & 2.2 & 13.9 & 81.8 \\
\hline $3006^{\prime} 2^{\prime \prime}$ & 814.5 & .09 & 3.47 & 1.5 & 0 & 4.5 & 13.4 & 77.2 \\
\hline $3016^{\prime} 2^{\prime \prime}$ & 1197.5 & .49 & 5.52 & 2.0 & .6 & 8.9 & 1.7 & 81.2 \\
\hline $3026^{\prime} 2^{\prime \prime}$ & 1245.2 & 2.27 & 11.32 & 2.8 & .8 & 4.2 & 10.1 & 70.8 \\
\hline $3036^{\prime} 2^{\prime \prime}$ & 1093.4 & .96 & 6.32 & 2.2 & .5 & 5.2 & 5.8 & 80.0 \\
\hline $3046^{\prime} 2^{\prime \prime}$ & 888.2 & .63 & 5.5 & 2.2 & 0 & 4.3 & 8.0 & 80.0 \\
\hline $3056^{\prime} 2^{\prime \prime}$ & 1194.6 & 1.06 & 7.48 & 2.6 & 0 & 3.6 & 8.5 & 77.8 \\
\hline $3066^{\prime} 2^{\prime \prime}$ & 1582.6 & -.21 & 4.47 & 1.7 & 0 & 3.0 & 13.6 & 77.2 \\
\hline $3076^{\prime} 2^{\prime \prime}$ & 634.0 & .78 & 1.96 & 1.5 & 0 & 5.3 & 12.6 & 78.7 \\
\hline $3086^{\prime} 2^{\prime \prime}$ & 991.5 & 1.45 & 6.53 & 2.4 & 0 & 4.7 & 9.8 & 76.7 \\
\hline $3096^{\prime} 2^{\prime \prime}$ & 675.6 & 1.25 & 4.50 & 1.6 & 0 & 4.2 & 12.9 & 76.8 \\
\hline $3106^{\prime} 2^{\prime \prime}$ & 649.0 & 1.45 & 3.55 & 1.2 & 0 & 2.1 & 16.8 & 76.4 \\
\hline $3116^{\prime} 2^{\prime \prime}$ & 861.0 & 1.28 & 3.52 & 1.3 & 0 & 0 & 14.7 & 80.5 \\
\hline $3126^{\prime} 2^{\prime \prime}$ & 961.6 & .97 & 6.65 & 2.2 & 0 & 2.5 & 10.2 & 78.4 \\
\hline $3136^{\prime} 2^{\prime \prime}$ & 937.1 & -.09 & 3.55 & 1.6 & 0 & 0 & 14.5 & 80.3 \\
\hline $3146^{\prime} 2^{\prime \prime}$ & 1171.5 & .85 & 7.63 & 2.2 & .6 & 0 & 10.0 & 79.7 \\
\hline $3.156^{\prime} 2^{\prime \prime}$ & 1902.5 & 1.09 & 14.46 & 4.5 & 1.6 & 3.4 & .6 & 75.5 \\
\hline $3166^{\prime} 2$ '" & 982.1 & 1.18 & 9.68 & 3.2 & .7 & 3.6 & 8.4 & 74.4 \\
\hline $3176^{\prime} 2^{\prime \prime}$ & 1080.6 & -.14 & 4.65 & 1.9 & 0 & 0 & 15.8 & 77.7 \\
\hline $3186^{\prime} 2^{\prime \prime}$ & 925.6 & 1.61 & 9.50 & 3.0 & 0 & 3.9 & 10.0 & 73.7 \\
\hline $31911^{\prime}{ }^{\prime \prime}$ & 1104.8 & -.41 & 2.17 & 1.7 & 0 & 4.2 & 11.9 & 80.0 \\
\hline 3201 ' 2 '! & 1271.9 & -.06 & 2.46 & 1.3 & 0 & 8.6 & 10.6 & 77.0 \\
\hline $3211^{\prime} 2^{\prime \prime}$ & 939.2 & .42 & 5.33 & 2.6 & 0 & 4.7 & 7.7 & 79.6 \\
\hline $3221^{\prime} 2^{\prime \prime}$ & 1107.8 & $=1.5$ & 6.27 & 3.1 & 1.0 & 3.8 & 4.7 & 81.2 \\
\hline
\end{tabular}




\begin{tabular}{|c|c|c|c|c|c|c|c|c|c|}
\hline $3231^{\prime} 2^{\prime \prime}$ & 1051.8 & - & .46 & 4.77 & 2.2 & 0.1 & 4.9 & 7.4 & 80.6 \\
\hline $3241^{\prime} 2^{\prime \prime}$ & 1576.7 & & .21 & 6.81 & 2.8 & 0.7 & 0 & 6.7 & 83.0 \\
\hline $3251^{\prime} 2^{\prime \prime}$ & 1260.9 & & .61 & 3.23 & 1.6 & 0 & 0 & 15.9 & 79.2 \\
\hline 3261 '2" & 1051.0 & & .03 & 0 & 0 & 0 & 0 & 19.9 & 80.1 \\
\hline $3271^{\prime} 2^{\prime \prime}$ & 1256.2 & & .16 & 13.91 & 4.5 & 1.6 & 5.6 & 1.0 & 73.5 \\
\hline $3281^{\prime} 2^{\prime \prime}$ & 1717.3 & & & 8.99 & 2.5 & 0.6 & 2.5 & 6.1 & 79.3 \\
\hline 3291 '2" & 1572.4 & & & 2.87 & 1.9 & 0 & 0 & 9.5 & 85.7 \\
\hline $3301^{\prime} 2^{\prime \prime}$ & 918.8 & & & 3.25 & 1.6 & 0 & 1.9 & 14.5 & 78.7 \\
\hline $3311^{\prime} 2^{\prime \prime}$ & 963.3 & & & 14.01 & 4.5 & 1.6 & 5.3 & 4.0 & 70.7 \\
\hline 3321 '2" & 1457.6 & & & 4.17 & 1.6 & 0 & 0 & 16.7 & 77.5 \\
\hline 3331 '2" & 1285.2 & & & 0 & 0 & 0 & 0 & 22.4 & 77.8 \\
\hline $3341^{\prime} 2^{\prime \prime}$ & 1208.7 & & & 0.09 & 0 & $\dot{0}$ & 0 & 22.1 & 77.9 \\
\hline 3351 '2"' & 1502.8 & & & 2.91 & 1.2 & 0 & 0 & 19.9 & 76.0 \\
\hline $3366^{\prime} 2^{\prime \prime}$ & 833.8 & & & & & & & & \\
\hline $3376^{\prime} 2^{\prime \prime}$ & $1612: 0$ & $<$ & 25 & 1,12 & 1.2 & 0 & 0 & 19.9 & 77.8 \\
\hline $3386^{\prime} 2^{\prime \prime}$ & 1659.3 & & & 5.28 & 2.5 & 0.6 & 2.9 & 12.5 & 76.2 \\
\hline $3396^{\prime} 2$ "' & 1574.4 & & & 0.11 & 2.0 & 0 & 0 & 19.8 & 78.1 \\
\hline $3406^{\prime} 2^{\prime \prime}$ & 1068.3 & & & 11.78 & 5.1 & 2.6 & 3.5 & 12.1 & 65.0 \\
\hline $3416^{\prime} 2^{\prime \prime}$ & 1302.5 & & & 2.16 & 1.0 & 0 & 0 & 19.6 & 77.2 \\
\hline $3426^{\prime} 2^{\prime \prime}$ & 1180.8 & & & 33.57 & 18.8 & 14.7 & 0 & 0 & 32.9 \\
\hline $3436^{\prime} 2^{\prime \prime}$ & 888.9 & & & 0.99 & 1.9 & 1.2 & 0 & 20.9 & 74.9 \\
\hline $346^{\prime} 3^{\prime \prime}$ & 1288.1 & & & 12.9 & 6.9 & 4.6 & 3.2 & 10.1 & 62.5 \\
\hline $3456^{\prime} 2^{\prime \prime}$ & 1776.8 & & & 3.59 & 1.4 & 0 & 2.8 & 16.3 & 75.9 \\
\hline $3466^{\prime} 2^{\prime \prime}$ & 1435.6 & & & 5.9 & 3.7 & 2.2 & 3.6 & 14.5 & 70.1 \\
\hline $3476^{\prime} 2^{\prime \prime}$ & 1460.0 & & & 1.56 & 2.0 & 1.0 & 0 & 20.8 & 74.7 \\
\hline $3486^{\prime} 2^{\prime \prime}$ & 1279.0 & & & 5.57 & 2.6 & 1.0 & 6.2 & 11.6 & 73.0 \\
\hline $3496^{\prime} 2^{\prime \prime}$ & 1158.3 & & & 22.12 & 8.2 & 4.5 & 4.8 & 3.8 & 56.6 \\
\hline
\end{tabular}




\begin{tabular}{|c|c|c|c|c|c|c|c|}
\hline $3506^{\prime} 2^{\prime \prime}$ & 1685.6 & 39.95 & 18.0 & 11.9 & 0 & .4 & 29.6 \\
\hline $3516^{\prime} 2^{\prime \prime}$ & 1762.8 & 14.55 & 6.5 & 4.0 & 2.5 & 11.8 & 60.6 \\
\hline $3526^{\prime} 2^{\prime \prime}$ & 1528.8 & 12.39 & 6.2 & 3.6 & 0 & 13.6 & 64.2 \\
\hline $3536^{\prime} 2^{\prime \prime}$ & 1773.4 & 0.76 & 2.1 & 0 & 2.5 & 18.6 & 75.0 \\
\hline $3546^{\prime} 2^{\prime \prime}$ & 1553.8 & 44.17 & 15.9 & 9.1 & 0 & 0 & 30.9 \\
\hline $3556^{\prime} 2^{\prime \prime}$ & 1082.7 & 18.87 & 8.0 & 4.9 & 5.1 & 5.6 & 57.6 \\
\hline $3566^{\prime} 2^{\prime \prime}$ & 1321.8 & 10.6 & 5.3 & 2.8 & 3.3 & 10.4 & 67.5 \\
\hline $3576^{\prime} 2^{\prime \prime}$ & 1845.7 & 2.95 & 3.8 & 1.9 & 2.1 & 10.7 & 78.6 \\
\hline $3586^{\prime} 2^{\prime \prime}$ & 1615.6 & 19.23 & 9.6 & 5.4 & 6.3 & 4.6 & 54.9 \\
\hline $3596^{\prime} 2^{\prime \prime}$ & 891.2 & 0.37 & 1.1 & 0 & 0 & 21.0 & 77.6 \\
\hline $3606^{\prime} 2^{\prime \prime}$ & 1166.8 & 0.12 & 1.4 & 0 & 0 & 21.7 & 76.8 \\
\hline $3616^{\prime} 2^{\prime \prime}$ & 1380.7 & 31.75 & 8.8 & 3.9 & 4.5 & .8 & 50.2 \\
\hline $3626^{\prime} 2^{\prime \prime}$ & 1230.3 & 31.77 & 12.2 & 7.0 & 4.2 & 1.9 & 42.9 \\
\hline $3636^{\prime} 2^{\prime \prime}$ & 983.3 & 0 & 0 & 0 & 0 & 22.4 & 77.6 \\
\hline $3646^{\prime} 2^{\prime \prime}$ & 1988.5 & 3.44 & 2.9 & 1.0 & 2.4 & 17.4 & 72.8 \\
\hline $3656^{\prime} 2^{\prime \prime}$ & 1733.0 & 0 & 0 & 0 & 0 & 22.1 & 77.9 \\
\hline $3666^{\prime} 2^{\prime \prime}$ & 1357.4 & $n$ & 0 & 0 & 4.8 & 1.6 .9 & 78.3 \\
\hline $3676^{\prime} 2^{\prime \prime}$ & 1356.9 & 2.56 & 1.7 & 0 & 6.6 & 9.4 & 79.7 \\
\hline $3686^{\prime} 2^{\prime \prime}$ & 1385.5 & 1.17 & 1.4 & 0 & 4.1 & 14.6 & 78.8 \\
\hline $3696^{\prime} 2^{\prime \prime}$ & 1307.6 & 0.5 & 0 & 0 & 0 & 20.2 & 79.3 \\
\hline $3706^{\prime} 2^{\prime \prime}$ & $M I S S I N G$ & & & & & & \\
\hline $3716^{\prime} 2^{\prime \prime}$ & 887.3 & 0.03 & 0 & $n$ & 0 & 19.1 & 80.9 \\
\hline $3726^{\prime} 2^{\prime \prime}$ & 1399.3 & 0.20 & 1.0 & 0 & u & 16.0 & 82.8 \\
\hline $3736^{\prime} 2^{\prime \prime}$ & 978.4 & 2.26 & 4.4 & 2.2 & 5.8 & 6.8 & 78.5 \\
\hline $3746^{\prime} 2^{\prime \prime}$ & 846.5 & 3.89 & 4.8 & 2.7 & 3.7 & 12.2 & 72.7 \\
\hline $3756^{\prime} 2^{\prime \prime}$ & 963.4 & 0.62 & 1.7 & 0 & 0 & 21.3 & 76.4 \\
\hline
\end{tabular}




\begin{tabular}{|c|c|c|c|c|c|c|c|}
\hline $3766^{\prime} 2^{\prime \prime}$ & 815.4 & 1.55 & 0 & 0 & 0 & 19.2 & 19.3 \\
\hline $3776^{\prime} 2^{\prime \prime}$ & 944.4 & 0 & 0 & 0 & 4.0 & 17.6 & 78.4 \\
\hline $3786^{\prime} 2^{\prime \prime}$ & 1517.9 & 1.14 & 0 & 0 & 6.6 & 14.4 & 77.9 \\
\hline $3796^{\prime} 2^{\prime \prime}$ & 1278.3 & 0.07 & 0 & 0 & 4.7 & 14.9 & 80.3 \\
\hline $3806^{\prime} 2$ " & 1191.1 & 1.7 & 1.8 & 0 & 7.0 & 11.0 & 78.5 \\
\hline $3816^{\prime} 2^{\prime \prime}$ & 950.2 & 0 & 0 & 0 & 4.7 & 16.5 & 78.8 \\
\hline $3826^{\prime} 2^{\prime \prime}$ & 1223.9 & 0.02 & 0 & 0 & 3.8 & 17.0 & 79.1 \\
\hline $3836^{\prime} 2^{\prime \prime}$ & 1152.1 & 0.12 & 0 & 0 & 4.8 & 13.2 & 80.9 \\
\hline $3846^{\prime} 2^{\prime \prime}$ & 1096.5 & 2.04 & 1.8 & 0 & 6.4 & 3.8 & 86.0 \\
\hline $30566^{\prime} 2^{\prime \prime}$ & 693.5 & 1.74 & 1.6 & 0 & 2.3 & 15.8 & 78.6 \\
\hline $3866^{\prime} 2^{\prime \prime}$ & 842.0 & 1.17 & 0 & 0 & 0 & 18.3 & 80.5 \\
\hline $3876^{\prime} 2^{\prime \prime}$ & 979.8 & 0 & 1.1 & 0.05 & 2.3 & 19.5 & 77.2 \\
\hline $3886^{\prime} 2^{\prime \prime}$ & 954.9 & 3.41 & 1.8 & 0 & 0 & 17.8 & 77.0 \\
\hline $3896^{\prime} 2^{\prime \prime}$ & 889.5 & 7.17 & 3.3 & 0.8 & 2.8 & 12.8 & 73.1 \\
\hline $3906^{\prime} 2$ ' & 986.1 & 0.09 & 0 & 0.2 & 0 & 22.2 & 77.5 \\
\hline $3916^{\prime} 2^{\prime \prime}$ & 1152.1 & 2.22 & 4.3 & 1.7 & 4.0 & 10.5 & 77.3 \\
\hline $3926^{\prime} 2^{\prime \prime}$ & 844.0 & 7.46 & 3.4 & 1.2 & 2.8 & 9.9 & 15.2 \\
\hline $3936^{\prime} 2^{\prime \prime}$ & $M I S S I N G$ & & & & & & \\
\hline $3946^{\prime} 2^{\prime \prime}$. & 970.1 & 0 & 2.2 & 0 & 2.2 & 18.7 & 76.9 \\
\hline $3956^{\prime} 2^{\prime \prime}$ & 385.0 & $\dot{U}$ & 0 & 0 & 0 & 22.4 & 77.6 \\
\hline $3966^{\prime} 2^{\prime \prime}$ & 401.7 & 0 & 2.3 & 1.0 & 0 & 20.6 & 76.1 \\
\hline $3976^{\prime} 2^{\prime \prime}$ & 867.7 & 0.42 & 0.9 & 0 & 0 & 21.9 & 76.8 \\
\hline $3986^{\prime} 2^{\prime \prime}$ & 980.0 & 13.36 & 4.4 & 1.7 & 3.2 & 10.3 & 67.0 \\
\hline $3.996^{\prime} 2^{\prime \prime}$ & 1109.3 & 32.24 & 13.8 & 6.0 & 4.5 & 0 & 43.4 \\
\hline $4006^{\prime} 2^{\prime \prime}$ & 925.9 & 0.33 & 0.9 & 0 & 0 & 21.6 & 77.2 \\
\hline $4016^{\prime} 2^{\prime \prime}$ & 328.7 & 1.06 & 1.8 & 0 & 0 & 21.4 & 75.8 \\
\hline $4026^{\prime} 2^{\prime \prime}$ & 980.4 & 36.31 & 15.7 & 7.6 & 0 & 2.3 & 38.1 \\
\hline
\end{tabular}


NOTES to Table I. Gas Analysis As A Function of Depth, We11 20403

1. These samples are immediately adjacent to samples analyzed 24 June 1976 and reported (Ref. 1, page B3). They were thus analyzed 352 days after the first set and 498-508 days after canning.

2. Significant traces of butane were noted in sample numbers $3426^{\prime}$, $3516^{\prime} 2^{\prime \prime}, 3546^{\prime} 2^{\prime \prime}, 3556^{\prime} 2^{\prime \prime}, 3586^{\prime} 2^{\prime \prime}, 3626^{\prime} 2^{\prime \prime}$.

3. $.12 \% \mathrm{H}_{2} \mathrm{~S}$ was found in can 非331'2".

4. Cans marked "missing" were not received by Juniata. 


\section{SECTION C}

STATUS AND DETAILED PLANS

FOR CONSTRUCTION OF BET/ISOTHERM SYSTEMS

Paul D. Schettler; : Jr.

Our goal is to have operative by next sumer two automated diffusion/ isotherm apparatuses capable of simultaneous operation via multi-tasking Fortran on a laboratory computer. The first system will be capable only of sub-atmospheric work but will be improved over the present system in three respects: temperature control, improved determination of "time zero" of diffusion runs, and semi-automation that will permit unattended running for several hours. The second system will, have generally the same capabilities as the first but will sacrifice some automation for the ability to operate at pressure up to at least 500 psi and probably 3000 psi. Table I (page. C3) details our tentative schedule in this regard; the construction schedule of the second system is not changed from that of the contract, but it is hoped. that the experience gained by conversion of the first system will be of value as many of the problems expected will be common to both.

Figure I (page C4) shows our apparatus as presently configured. The modifications necessary are to replace the valves $V_{1}$ and $V_{2}$ by automatic valves operable by computer. In addition, a line which controls the pressure of gas introduced will be modified by inclusion of a third automatic valve. The effect of these modifications will be several-fold. First, a complete isotherm or diffusion constant can be run without human interference, permitting increased productivity, particularly during the school year. Second, the opening of $\mathrm{V}_{1}$ can be timed by computer control, eliminating a $5 \%$ error resulting from the present timing procedure. Third, the temperature control can be improved since the valves can be bolted to a thermostatically-controlled plate and then completely insulated on all other surfaces. 
The details of construction of the second systen will depend on the experience gained with the first; it is presently expected that the higher pressures may result in less automatic operation of it.

The BET/diffusion apparatus as presently configured is easily capable of detecting temperature changes within $.005^{\circ}$, and temperature fluctuations must be kept within this limit to fully utilize the capability of our diffusion/ isotherm apparatus. This posed a problem for automation in that the usual solenoid valve heats a few torrs of degrees by virtue of IR heating. This problem was resolved by using Skinner "Magna Latch" valves that require only a $15 \mathrm{msec}$ plus or minus pulse to turn them on or off. It was desired to control the valves either manually or with computer software via a logic bit on the NOVA General Purpose Interface Board, but this required an additional hardware interface to change the TTL logic of the interface board to appropriate $24 \mathrm{~V}$ 2 amp pulses to the valves. This interface has been constructed and, after some modifications to prevent $r f$ noise from the relay contacts from affecting the logic circuits, is now operative. 
I'ABLE I

SCHEDULE FOR CONSTRUCTION

(TENTATIVE)

June July Aug Sept Oct Nov Dec Jan Feb Mar Apr May

1. Construction of C

Skinner Valve/

GPI interface

2. Construction of $\quad X \quad x \quad$ C

lst production

apparatus

3. Sottware

$\begin{array}{lllllll}\mathrm{X} & \mathrm{X} & \mathrm{X} & \mathrm{X} & \mathrm{X} & \mathrm{X} & \mathrm{C}\end{array}$

construction

(FORTRAN) for

automatic

operation

4. 2nd (high

$\mathrm{X} \quad \mathrm{X} \quad \mathrm{C}$

pressure) system

construction

5. Software transfer

$\mathrm{x} \quad \mathrm{C}$

to new eyetcm 


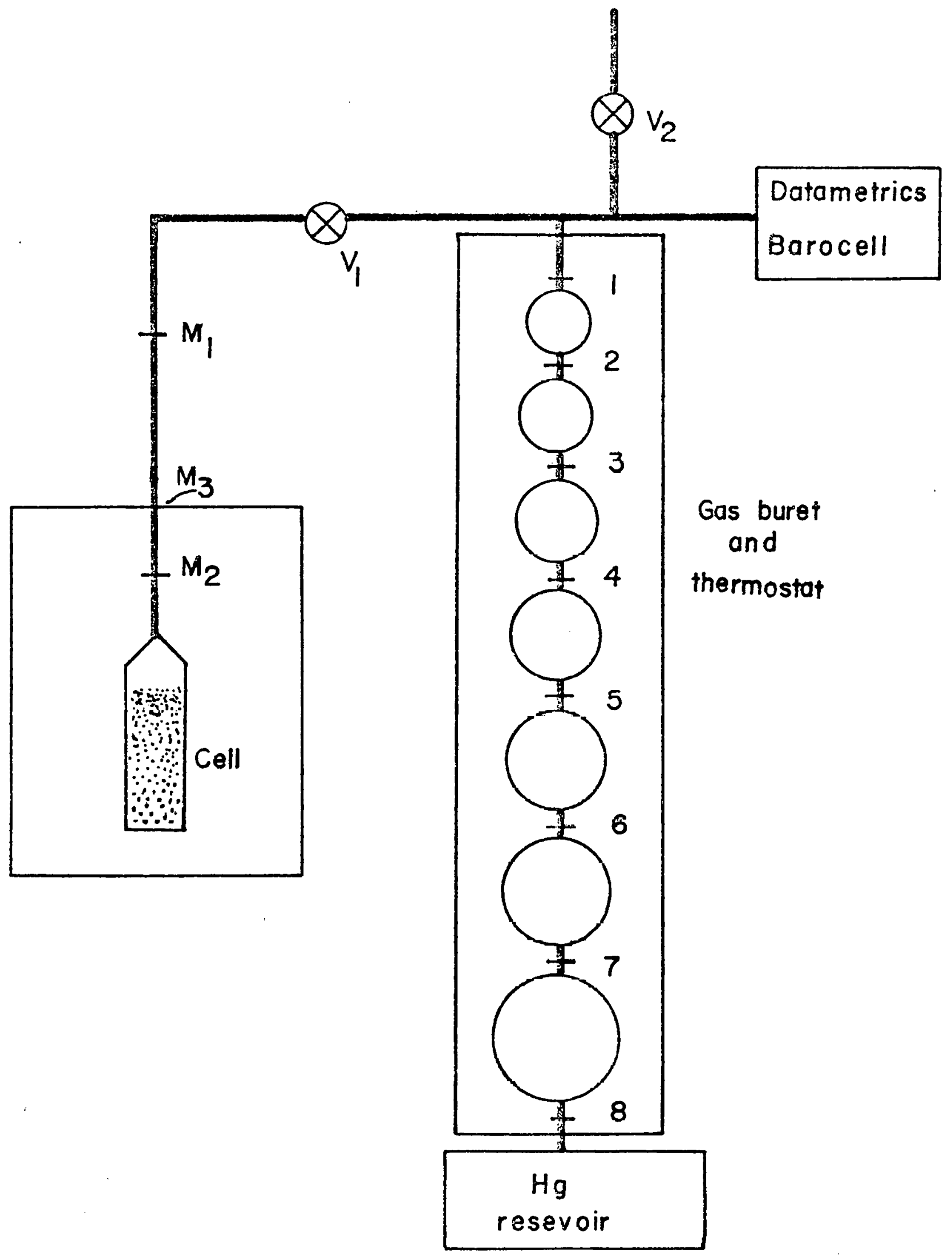


DESIGN AND CONSTIRUCTION

of SKINNER MAGNA LATCH VALVE TO NOVA Digital, I/O INTERFACE

Dale L. Wampler

Figure I (page D3) shows the wiring diagram for the interface as designed and constructed. The 74122 and 74121 chips are one shots (monostable oscillators). The 7476 chip is a dual JK flip-flop with preset and clear. Only half of the chip is used for each valve.

The double throw momentary normally open switch is used to momentarily ground (logic 0 ) pin 5 of one of the 74121 one shots. The $0 \rightarrow 1$ transition, upon release of the switch, triggers a.I logic pulse on pin 6 of duration determined by the resistor and capacitor on pins 10, 11, and 14 .

The upper one shot (74121) controls the latch relay. It can be triggered by momentarily placing the control switch in the up position. The resulting pulse is about $20 \mathrm{msec}$. which throws the latching relay for about $20 \mathrm{msec}$ providing a 24 volt pulse (red + , black -) to the valve. A $1-0$ pulse of the same length from pin 1 presets the flip-flop into the on position turning on the LED indicating that the valve is latched open. The latch one shot can also be triggered by a $1 \rightarrow 0$ transition on pin 4 resulting from a pulse from the upper 74122 one shot. The upper 74122 one shot will produce a short $0-1$ pulse on pin 8 when a 0-1 transition appears on pin. 3 from the computer output bit. The resulting pulse on pin 8 is fed to pin 4 of the 74121 one shot which triggers the latching relay control pulse.

The releasing relay pulse circuit functions in a slmilar manner to the latching circuit. The differences are as follows:

1. The pulse generated by the release one shot is about $45 \mathrm{~m} \mathrm{sec}$.

2. The 1-0 pulse from the release one shot clears the flip-flop, turning off the LED. 
3. $\Lambda I \rightarrow 0$ transition in the computer bit causes a pulse from the 74122 (lower) one shot to trigger the 74121 release one shot.

4. The release relay places $2 /$ VDC on the valve such that the black wire is positive and the red wire is negative.

At the present time we have three of the above circuils mounted on a PC board and mounted in turn on a chassis with LED indicators and manual control switches (for optional use). Thus the electronic hardware construction for the first phase of the BET/diffusion apparatus automation is complete. The manual control switches will permit use of the apparatus during the rather formidable period of software development. 

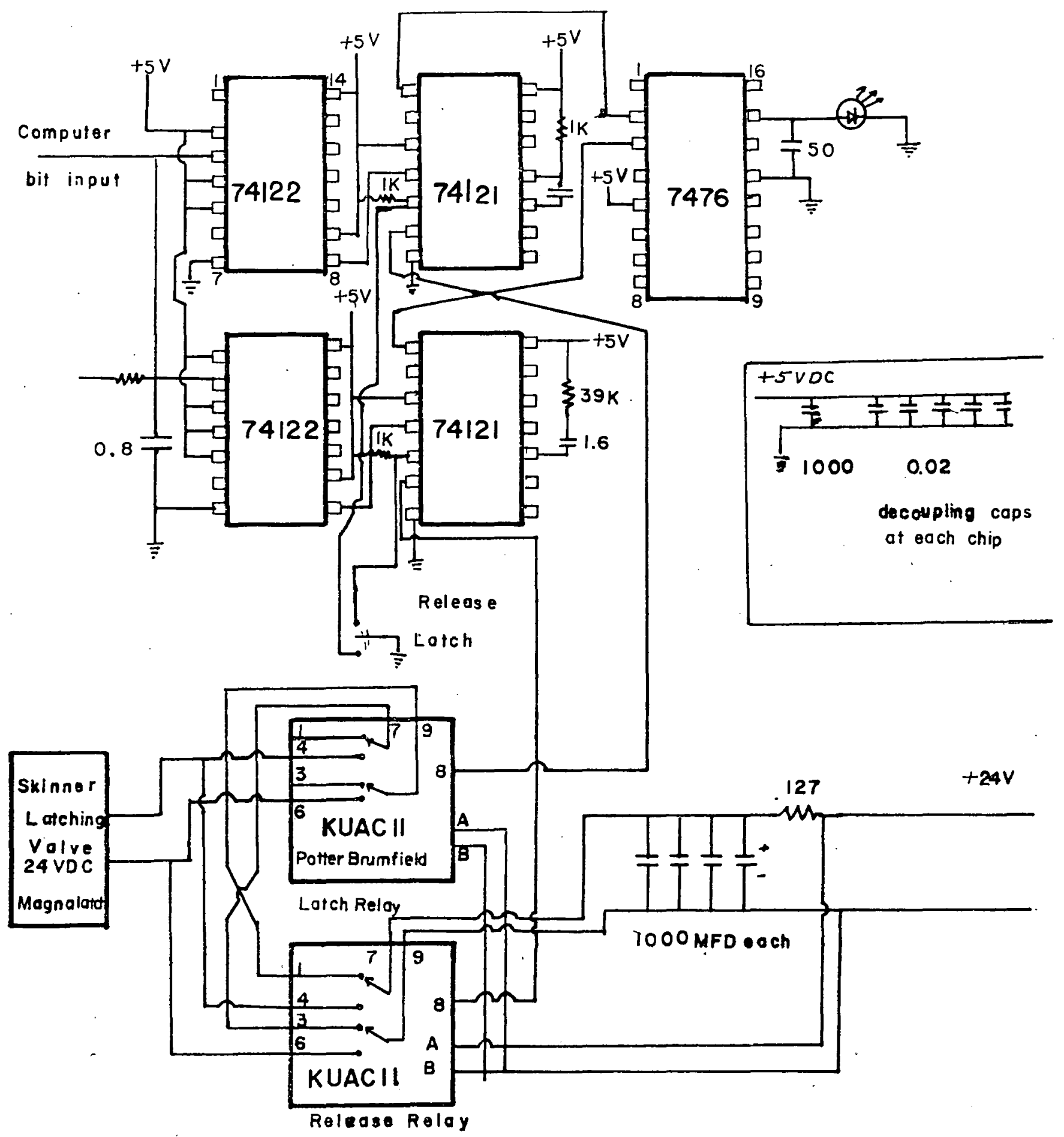
THE RELATIONSHIP OF

THERMODYNAMIC AND KINETIC PARANETERS TO WELL PRODUCTION IN DEVONIAN SHALE

by

Paul D. Schettler, Jr.

Dale L. Wampler

Philip J. Sipling

Donald J. Mitchell

Juniata College

Huntingdon, Pennsylvania 16652

\begin{abstract}
A mathematical model describing production of gas from wells in Devonian shales is introduced, and the extent of agreement with existing productivity data is discussed. Parameters needed for this model include the diffusion constant of gas through the rock and the sorption isotherms of gas within the rock. Methods and results of measurements of these important parameters made in our laboratories are described and discussed.
\end{abstract}

\title{
INTRODUCTION
}

This paper reports the results of efforts to model in the laboratory the process by which natural gas is released from tight formations (such as Devonian shales). The instrument for these studies is an apparatus in which a shale sample is initially equilibrated at some constant gas pressure; after equilibrium is reached, the pressure on the sample is suddenly changed and the rate and amounts of gas produced are monitored. The conceptual similarity of this laboratory process to the degassing of an underground reservoir is reflected in the similarity of gas loss curves produced in the laboratory with production rate curves of actual wells, except for differences in gas evolved and the time scale of evolution.

It is generally accepted that optimum production occurs in wells drilled into highly fractured areas. These fractures serve as conduits between the gas-producing rocks and the well bore. Initially, the gas in the fractures is in equilibrium with gas sorbed in the source rock; however, upon intersection of the fracture system by a we 11 bore, the pressure in the fractures drops discontinuously, and the source rock evolves gas until equilibrium is re-established at the new pressure. The mathematical treatment of the rate of diffusion into the well bore as a function of time is thus similar to that of laboratory samples undergoing a discontinuous pressure decrease, the differences lying primarily in questions of geometry, magnitude of rock involved, and size of initial pressure drop.

This paper deals with three main topics. First, the ideas discussed above are presented in quantitative form. It is shown that the diffusion constant of methane in shale and the extent and frequency of fractures collectively arc the

Frepared tor ERDA under Contract No. E(40-1)-5197. 
determining parameters of well production. Of these three factors, the first two are particularly amenable to laboratory measurement; the second and third sections of this paper deal with efforts in this regard.

\section{THH:ORFTTCAL}

The purpose of this section is, first, the mathematical description of the underground processes that lead to gas production from tight formations and, second, the comparison of that description to the mathematical description of the degassing of rock in laboratory configurations.

Production from wells in relatively impermeable formations depends upon drilling into highly fractured areas and/or creating them artificially after the well has been drilled. These fractures serve primarily as conduits from the gas-bearing source rock to the well bore. The amount of gas diffusing out of a shale into a fracture (held at a low pressure) is given by $(1,2)$

where

$$
\text { 1) } \begin{aligned}
M_{T} & =2\left(C_{2}-C_{0}\right) A\left(\frac{D t}{\pi}\right)^{\frac{1}{2}} \\
\frac{d M_{T}}{d t} & =\left(C_{2}-C_{0}\right) A\left(\frac{D}{\pi^{t}}\right)^{\frac{3}{2}}
\end{aligned}
$$
$A$ is the area of rock degassing.
$\mathrm{C}_{2}$ is the initial concentration of gas in the rock.
$\mathrm{C}_{0}$ is the concentration of gas in the rock as $t \rightarrow \infty$.
$D$ is the diffusion constant.
$t$ is the time.

Over a ten year period, for reasonable values of parameters for Devonian shale (D $=5 \times 10^{-7} \mathrm{~cm}^{2} / \mathrm{sec}, C_{2}-C_{0}=3 \mathrm{~cm}^{3}$ gas $/ \mathrm{cm}^{3}$ rock), $40 \mathrm{~cm}^{3}$ gas (STP) would be produced for each square centimeter of fissure wall area. This amount of gas is clearly much larger than the amount of gas contained between the walls of the average fracture, thus leuding oupport tn the concept that the rock is the source of the gas and that fractures serve as conduits. It is interesting $t o$ noto that the production curve predicted by equation 2 ) is high production over a relatively short period followed by a long call. In fact, $32 \%$ of the total gas produced over a 20-year period is produced in the first two years, in agreement with some qualitative reports of well production from some producing wells by Roth (3) and Torrey (4). Whereas initial well production is large, the inverse square rout dependence on time implies that after the initial large production reduced production will occur unabated for many years, again in agreement with many reports of the longevity of gas shale wella.

The upper curve of Figure I shows some actual production data points (5) and an inverse square root fit versus time as the solid line. Although the fit for that well is good, it is clear that not all wells display such a simple relationship. In particular, as the lower three curves show, the initial high production rate may, to a variaty of degrees, be missing. 
Flattened production curves result from a mathematical viewpoint if it is assumed that an additional constriction exists at the surface of a fracture or along the fracture to the well bore that impedes the diffusive process of gas from the bulk rock. Such surface modification would be expected to occur at slickensides wherein an impermeable-looking, glaze-like finish is formed on the rock. Alternatively, mineralization may occur within the fracture, plugging the microporous surface structure of the shale. Constrictive effects along the fracture would be expected when a narrow fracture is "overloaded" by a large gas flow. All of these effects, which might be expected to be common occurrences in actual situations, should result in flattened (and decreased!) we 11 productivity curves.

The lower curves in Figure $I$ are fits taking in account constrictive effects of varying degrees of importance. The equation of $f$ it is

$$
\text { 2) } \begin{aligned}
\frac{d M_{T}}{d t} & =\frac{D\left(C_{2}-C_{0}\right)}{g} \exp \left(z^{2}\right) \operatorname{erfc}(z) \\
z & =\frac{D^{\frac{3}{2}}}{g} t^{\frac{1}{2}}
\end{aligned}
$$

Equation 2) has been discussed in detail elsewhere (6).

Briefly, $g$ is a constrictive parameter corresponding to some kind of impermeable coating on the fracture surface. The more impermeable the coating, the larger $g$ is; conversely, for decreasing constrictive effects $g$ approaches zero and equation 2) approaches equation 1 ). Figure II shows this effect explicitly.

The middle curve is simply the lower curve of Figure $I$ with $g=6.318$. The upper and lower curves are with identical parameters (same fracture area, same bulk rock diffusion constant and gas concentration) except that $\mathrm{g}=0$ and $30 \mathrm{~cm}$ for the upper and lower curves respectively. It is clear from Figure II that the effect of constrictions is to decrease markedly total production and flatten it in respect to time.

In contrast to the flattening observed in wells, most laboratory samples will give somewhat steeper curves than predicted by a simple $t^{-\frac{1}{2}}$ law; specifically experimental points will follow equation 1) closely at low $t$ but fall below the theoretical curve at large times. This feature may not be limited to laboratory samples; in fact the points of the most productive curve of Figure I form a slightly steeper curve than the fit shown. The explanation for this phenomenon lies in the geometry of the fractures in the case of a well and the particle shapes in the case of laboratory samples; in fact the applicability of equations 1) and 2) is limited to the case where the depletion zones (6) associated with each fracture do not interfere. As a surface degases, the rock behind the surface becomes depleted to an ever-increasing extent, this zone of depletion initially extending only a short way into the rock but the extension increasing with time. Specifically

$$
\text { 3) } \mathrm{d} \cong \sqrt{\mathrm{Dt}}
$$


where $\mathrm{d}$ is the depletion zone mentioned above. When $\mathrm{d}$ is much smaller than the dinensions associated with rock fragments or distances between fractures, equations 1) and 2) can be expected lo be obeyed. Ilowever, as time increases, d increases until it eventually becomes of the order of the fracture or particle dimensions. At this point the depletion zone from one fracture starts to move into areas already depleted by another fracture, and gas production lapels uIf below that predicted by the $t^{-\frac{1}{2}}$ law.

Exact functions exist and have been utilized for several laboratory degassing situations, as is discussed elsewhere $(6,7,8)$. Although it would appear from Figure I that geometric effects are not important in wells, they may nevertheless sometimes be detectable. As discussed elsewhere (6) the anomalous steepness of the top curve of Figure I corresponds to a mean distance between fractures of $65 \mathrm{~cm}$. Anumalous steepness and large productivity may thus be linked together as both are indications of production from highly fractured zones.

\section{DIFFUSION CONSTANTS}

Diffusion constants and permeability constants are closely related.

$$
\mathrm{D}=\mathrm{P} / \mathrm{K}
$$

where $D$ is the diffusion constant, $P$ is the permeability constant, and $K$ is the solubility of gas in the rork,

$$
\mathrm{C}=\mathrm{KP}
$$

where $C$ is the equilibrium concentration of gas in the rock, and $P$ is the applied pressure. Diffusion (and/or permeability constants) can be measured by determining the rate that gas passes through a cut slab of sample or alternatively it can be deduced from the rate a sample of rock degases. The latter method has the advantages chat ic ls qulckel, ulten taking only a fcw minutes to get a measurement, and is more closely related to the actual underground degassing process.

In our procodure, we first equilihrate the sample at a constant pressure. For sieved samples, this typically takes less than an hour and is done on the measuring apparatus. For slabs equilibrated to 1 atm methane, the equilibration takes several days and is done before placing the sample on the measuring apparatus. As shown in Figure III, the cell is separated from a carefully calibrated volume (9) by a valve. After measuring the initial equilibrium pressure, the valve is closed, and the volume associated with the buret, etc., changed to a new pressure (typically evacuated). An automatic data-taking routine associated with a NOVA 1220 laboratory computer is started which takes pressure readings from the Datametrics Barocel. Then the valve between the cell and the calibrated volume is opened. The pressure changes resulting are monitored at a data collection rate of 25,000 readings/second for a period of several minutes for particles and about one-half hour for slabs. The pressure changes which occur after the initial pressure drop are due to the degassing of the sample. The amount of gas given off follows (initially) a $t^{\frac{1}{2}}$ law whose slope is interpretable in terms of the diffusion constant as discussed earlier for wells. The detailed procedures for slabs and particles are somewhat different, and the details are discussed elsewhere $(7,8)$. 
Table I shows results obtained at a variety of depths from We 11 非20403 drilled by Columbia Gas Corporation in conjunction with the Eastern Gas Shales Project. The average methane diffusion constant is $6.56 \times 10^{-7} \mathrm{~cm}^{2} / \mathrm{sec}$ with a standard deviation of $\pm 4.18 \times 10^{-7} \mathrm{~cm}^{2} / \mathrm{sec}$. This range represents the approximate range of diffusion constants within the Devonian shale sequence (at the Lincoln County well, etc.). There is a dependence of the diffusion constant upon the temperature and/or type of gas used. For example, our $77^{\circ} \mathrm{K}$ $\mathrm{N}_{2}$ diffusion constants average 2.3 times the ice temperature methane constants although individual comparisons can deviate from this figure. There is a dependence of diffusion constant upon particle size. For data reported elsewhere (8), $\mathrm{N}_{2}$ diffusion constants at $77^{\circ} \mathrm{K}$ for $500-700 \mu$ averaged 4.5 times the value for 175-350 $\mu$ mesh size. As a general rule, work on slabs supports this contention. A sample at $3886^{\prime} 24^{\prime \prime}$ gave a diffusion constant of $2.5 \times 10^{-7} \mathrm{~cm}^{2} / \mathrm{sec}$ for $175-350 \mu$ mesh size, $15.4 \times 10^{-7} \mathrm{~cm}^{2} / \mathrm{sec}$ for $500-700 \mu$ mesh size, and $116.1 \times 10^{-7} \mathrm{~cm}^{2} / \mathrm{sec}$ for a slab of shale at $3886^{\prime}$ of dimensions $27.88 \mathrm{~cm}^{2}$ by $.72 \mathrm{~cm}$ thick. This size effect can be accounted for by two possible mechanisms. It may be that highly impermeable components of shale fracture more easily into material of smaller mesh size. The second possibility is that the grinding process decreases the number of microfractures or other $z$ ones of weakness associated with high diffusivity by cleaving along, hence eliminating them. Our data supports the second hypothesis; the first hypothes is would suggest that slab diffusion would be intermediate between large and small particles, an effect which has not been observed to date. Further, there is no obvious difference between the large particles and the small ones as observed under an optical microscope.

The effect of manner of sample preparation may have some effect upon results. Table II snows an increase of diffusion in samples prepared by percussion mortar. Optical examination suggests that the samples prepared by ball mill are abraded more than samples prepared by percussion mortar. If this is the case, diffusion of samples prepared by percussion mortar ought to be more representative of "bulk shale" than those prepared by ball mill. Table III shows a very interesting effect observed with slabs. The first and third samples show a methane diffusion for slabs that is some 4.5 times larger than for particles from the same shale. However, the second sample of Table II shows a slab diffusion that is only $15 \%$ of the particle diffusion. This surprising result may be understood in terms of surface preparation. Before making the measurements, the slab surfaces are ground down by peeling the surface down with a chisel. Whereas usually this results in a dull-looking surface, for the anomalous result in question a shiny, impermeable-looking, slickenside-like surface resulted. We believe that the effect of rubbing with a chisel on this sample was to produce a thin impermeable layer that lowered the rate of outgassing by about a factor of 40 over that produced from surfaces split by a percussion mortar. Work on this tantalizing but speculative area is continuing.

\section{ISOTHERMS}

The value of the determination of isotherms is at least twofold. First, it allows the estimation of concentration of gas in the rock surrounding a well given only the initial wellhead pressure. In this sense an isotherm plays the same role as porosity in standard oil technology. However, the concept of an isotherm is more general because it is a measure of all gas in the rock, that in open pores, that adsorbed on the surface of minute clay particles, and that dissolved in some kerogen or other material entrained in the rock. Some 
practical implications of this have been discussed elsewhere (10). The second value of an isotherm is that it permits, at least to some degree, the determination of which of these mechanisms of entrainment are operative--open porosity, adsorption, or solution. More discussion on this point has been made elsewhere (11).

Figure IV shows some typical isotherms, showing the degree of entrainment of ethane, methane, argon and helium, all on the same sample. It should be noted that these isotherms are all straight lines within this region and hence can be associated with a "porosity." However, the porosity calculated from each gas is different, corresponding to $40 \%, 13 \%, 7 \%$, and $3 \%$, for $\mathrm{C}_{2} \mathrm{H}_{6}$, $\mathrm{CH}_{4}$, An, and He respectively. As this makes no physical sense for open pores, one can only conclude that whit is measured is an "effective porosity" which includes substantial amounts of adsorption and/or solution. A corollary to this is that the most appropriate measure of porosity to be associated with natural gas production is "methane porosity" obtained by direct measurement of amount of methane sorbed as a function of pressure.

In addition to the data reported in Reference 14, we have measured room temperature isotherms for the 17 samples in Table $I$. If it is assumed that helium sorption is due only to penetration of the open pores, the straight line He plots can be reinterpreted in terms of a helium density (wt. of sample/ volume of unpenetrated samples). Helium densities average $\sim .04 \mathrm{~g} / \mathrm{ml}$ higher than bulk densities corresponding to an average porosity of $1 \%$. The vol. gas/ vol. rock/torr for methane given in Table $I$ is that in excess of that assoclated with the pore volume (as determined by the He isotherms). It is useful to note that the methane isotherms slopes are grouped around $3.27 \times 10^{-4}$ vol. methane/vol. rock/torr $( \pm 42 \%)$ even though an effort was made to include a variety of lithologies in the 17 samples included in Table $I$.

In addition to room temperature isotherms, we have also determined isotherms of $\mathrm{N}_{2}$ determined at liquid nitrogen temperatures. 'l'he value of thls measurement is several-fold. First, if one assumes that the kerogen freezes to an impermeable solid at liquid nitrogen temperatures, then any sorption that takes place must be adsorption on the various surface areas associated with the small particles of clay minerals. Under these conditions a standard BET analysis is possible (13). We find good fits to the BET isotherm which lends support to the adsorption model (at least at luw Leuperatures) and results in a determination of the surface area available for adsorption. For shale samples that we have measured, this varies from a few tenths to several meters squared per gram (14). This is a small fraction of the surface area associated with clay minerals (illite is $92 \mathrm{~m}^{2} / \mathrm{g}$ (15)), but nevertheless sufficient to show that sufficient adsorptive capacity exists within Devonian shales to account for the amounts of methane observed.

In Table $I$, we have shown the nitrogen BET surface areas in terms of the volume of gas that would be required to cover the available surface area with a monolayer. This should represent the maximum amount of methane that can be adsorbed onto surface areas within the rock, as significant multilayer adsorption of methane would not be expected at temperatures present in the ordinary well.

A major point of interest concerns the degree of correlation between the isotherm parameters of Table I and the amount of gas found in the rock. We received the 17 samples reported in Table $I$ in sealed cans along with about 
213 other samples taken at 10 -foot intervals down the we11. After a wait of 142-156 days, the atmosphere in the cans were analyzed for $\mathrm{O}_{2}, \mathrm{~N}_{2}, \mathrm{CH}_{4}, \mathrm{C}_{2} \mathrm{H}_{6}$, $\mathrm{C}_{3} \mathrm{H}_{8}, \mathrm{CO}_{2}, \mathrm{H}_{2}$, and $\mathrm{H}_{2} \mathrm{~S}$ by gas chromatography $(17,18)$. The results for the 17 samples of Table $I$ is summarized in Table IV. Several features are worthy of note. First, there is no close correlation between the parameters of Table I and gas content. In particular, gas content ranges over several orders of magnitude from sample to sample wherein the parameters of Table $I$ are relatively constant. This may be expected because the isotherms of Table I essentially measure the capacity for gas content as a function of pressure. Since these remain relatively constant from strata to strata and gas content varies, it is concluded that the original gas pressure in the rock must vary considerably in various parts of the well. A consequence that follows from this is that even over geologic time the thermodynamic equilibrium of methane does not seem to be reached even in strata as close together as about 50 feet.

Several other features of Table IV include the observation that often the desorption of hydrocarbons is closely correlated with approximately equimolar adsorption of nitrogen and oxygen originally present in the can at sealing time so that the total pressure remains constant. Oxygen nitrogen ratios vary from can to can and are generally too high to account for the loss of air by can leakage; this suggests some kind of molecule-for-molecule displacement mechanism. Methane, ethane, and propane usually appear in decreasing amounts in concordance with the observations of other investigators $(19,20)$. Finally, gas production seems relatively well correlated with the appearance of black shale as noted by the well site core description, although this is certainly not $a$ hard and fast rule.

\section{CONCLUSIONS}

A major conclusion would seem to be that the isotherm and diffusion parameters are not sensitive functions of depth or 1ithologic type of Devonia.. shale at least in the vicinity of the 非 20403 well. If this holds for other iocations as we 11 , this means that averaged parameters can safely be used in we 11 modeling studies of the type discussed in the introduction - a great simplification.

Apparently even zelatively close layers of rock within the Devonian shale sequence are not in quilibrium with each other in respect to the chemical potential of hydrocarbon gases. More work needs to be done in this area; in particular we are interested in measuring the diffusion constants of slabs cut parallel to the bedding planes. A practical consequence of non-equilibrium is that the well bore becomes a mechanism by which equilibrium can be obtained. Gas from an outgassing region can be trapped by an adsorbing region; thus it is lost to production. The possible magnitude of this effect is under study in our laboratories.

Finally it seems possible to reach some speculative conclusions pinpointing the slickenside nature of many natural fractures as a source of slow well production. Fits to at least some available production data point to the presence of slickensides or some similar localized constriction in the passage of gas from the source rock to the well bore. This correlates with comments of various personnel involved with cataloging natural fractures (21) that most natural fractures are slickensided or mineralized. At the moment, pinpointing slickenside formation as a major culprit in the observed constrictive 
effects is supported by a single laboratory measurement. This is not to imply that slickensided fractures are detrimental to production (tolal production is the sum of the production from each fracture), but rather that the removal of constriction from existing fractures will itself raise production significanlly. Work on the role of slickensides in well constriction and their possible removal is continuing.

\section{ACKNOWLEDGMENT}

The authors wish to thank the Energy Research and Development Administration under whose auspices this work was accomplished under Contract No. E(40-1)-5197. In addition, the authors wish to thank D. Steven Hench, Eugene Boden, Martha Linton, Jay Nelson, Eric Jensen, Sharon Steckbeck, and Linda Hoeflich, who collected much of the data.

\section{REFERENCES}

1. Schettler, P., Wampler, D., Mitchel1, D., and Russey, W., "Degasification of Devonian Shales," ERDA Symposium on Devonian Shales, Morgantown, W. Va., 1976.

2. Crank, J., The Mathematics of Dittusion, Uxford Press, Lunduil, 1956.

3. Roth, E. E., "Natural Gases of the Appalachian Basin," in Natural Gases of North America, Beebe, B. W., Ed., AAPG, 1968.

4. Torrey, P. D., "Summary of Natural Gas Fields nf New York and Pennsylvania," in The Geology of Natural Gas, Ley, H. A., Ed., AAP, 1935.

5. Bagna 11, W. D., and Ryan, W. M., "Geology, Reserves, and Production Characteristics of the Devonian Shale in Southwestern West Virginia," ERDA Symposium on Devonian Shales, Morgantown, W. Va., 1976.

6. Schettler, P., "Gas Production in Shale Wells: Constrictive and Geometric Effects," ORO-5197-1, Study of Hydrocarbon-Shale Interaction, Progress

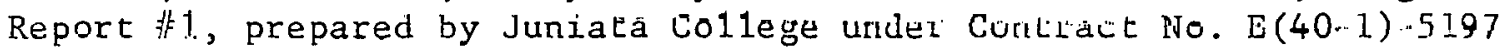
for USERDA, 1976.

7. Jensen, E., Steckbeck, S., Schettler, P., "Dlffusiun Cüstants in Devonian Shalc," in ORO-5197-1 (see Ref. 6).

8 . Schetiler, P., "The Peagurcment of Diffusion constants Assnciated with Sorption/Desorption from Slabs of Shale," in ORO-5197-2, Study of Hydrocarbon-shale Incerdcl lon, Frogless Report \#2, proparad by Juniata College under Contract No. E(40-1)-5197 for USERDA, 1976.

9. Jensen, F.; Schettler. P., "Calibration of the Sorption Studies Apparatus," in ORn-5197-1. (sce Ref. 6).

10. Schettler, P., "The Relationship of Methane Isotherms to Wel1 Production," In ORO-5197-3, Study of Hydrocarbon-Shale InLelaction, Progress Report 非, prepared by Juniata College under Contract No. E(40-1)-5197 for USERDA, $197 \%$.

11. Jensen, E., "Cumparative Adsorption Isotherms of Cras-Rearing Devonian Shales," in 0RO-5197-2 (see Ref. 8).

12. Jensen, E., Schettler, P., "Room Temperature Isotherms as a Function of Gas and Temperature on Core Samples from Well \#20403 in Lincoln County, West Virginia," in ORO-5197-3 (see Ref. 10).

13. Brunauer, S., Emmetl, P.H., and Teller, E., J. Am Chem. Sor., 60.309 (1938).

14. Jensen, E., Schettler, P., "Isotherms of Devonian Shales," in ORO-5197-1 (see Ref. 6). 
15. Nelson, R. A., and Hendricks, S. B., "Specific Surface Areas of Some Clay Minerals, Soils, and Soil Colloids," Soil Sci., 56, 285 (1944).

16. Hoeflich, L., Jensen, E., Wampler, D., Schettler, P., "Analysis of Hydro-

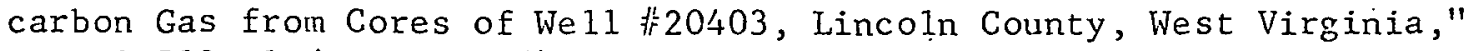
in ORO-5197-1 (see Ref. 6).

17. Jensen, E., Schettler, P., "Analysis of Hydrocarbon Gases from Cores of We11 \#20336, Martin County, Kentucky, and Tristar 非 1 We11 in Effingham County, Illinois," in ORO-5197-3 (see Ref. 10).

18. Schettler, P., Wampler, D., Mitche11, D., Sipling, P., ORO-5197-4, Study of Hydrocarbon-Shale Interaction, Progress Report 144 , prepared by Juniata College under Contract No. DY-76-S-05-5197, 1977.

19. Snyder, J., Schorr, J.R., "3rd Technical Progress Report," Battelle Laboratories, ORO-5203-3, prepared under contract No. E(40-1)-5205 for USERDA (1977).

20. Zielinski, R. E., "Physical and Chemical Characterization of Devonian Gas Shale," Mound Laboratory, prepared under U.S. Government Contract No. EY-76-C-04-0053, 1977.

21. Private communication, Eric Smith, Columbia Gas Service Corporation, for example.

\section{FIGURE CAPTIONS}

FIGURE I (page 12)

Flow rate (million cubic ft/da.) is plotted against time (years). Data is from Ref. 5. The lines are fits as described in the text. Values of the parameters are as follows from upper to lower curves.

$$
\begin{aligned}
& \text { Size }\left(\text { meters }{ }^{2}\right) \times 10^{11} \mathrm{~g}(\mathrm{~cm}) \\
& 1.210 \\
& \begin{array}{ll}
.845 & 4.79
\end{array} \\
& .506 \quad 6.02 \\
& .254 \quad 6.32
\end{aligned}
$$

FIGURE II (page 13)

The effect of localized constrictions on well production. The lower curve shows production from a well with a high degree of localized construction. In the upper curves these constrictions are progressively removed. Note that production increases and shifts to lower times.

\section{FIGURE III (page 14)}

Our laboratory apparatus. The slabbed or ground sample is placed within the ccll. Initially there is a known pressure differential across $V_{1}$. After $V_{l}$ is opened, the Datametrics Barocel monitors pressure changes as a function of time. The calibrated buret permits quantitative interpretation of the pressure readings in terms of rates and amounts of gas production.

FIGURE IV (page 15)

Moles of various gases sorbed on a 5.6 gram sample as a function of pressure at $30^{\circ} \mathrm{C}$. The slopes correlate well with the molecular polarizabilities suggesting a simple adsorption mechanism for entrainment of gas in the rock. 
TABLE I. DIFFCSION AND ISJTHERM PARAMECERS, We 11 \#20403, Lincoln Courty, West Virginia

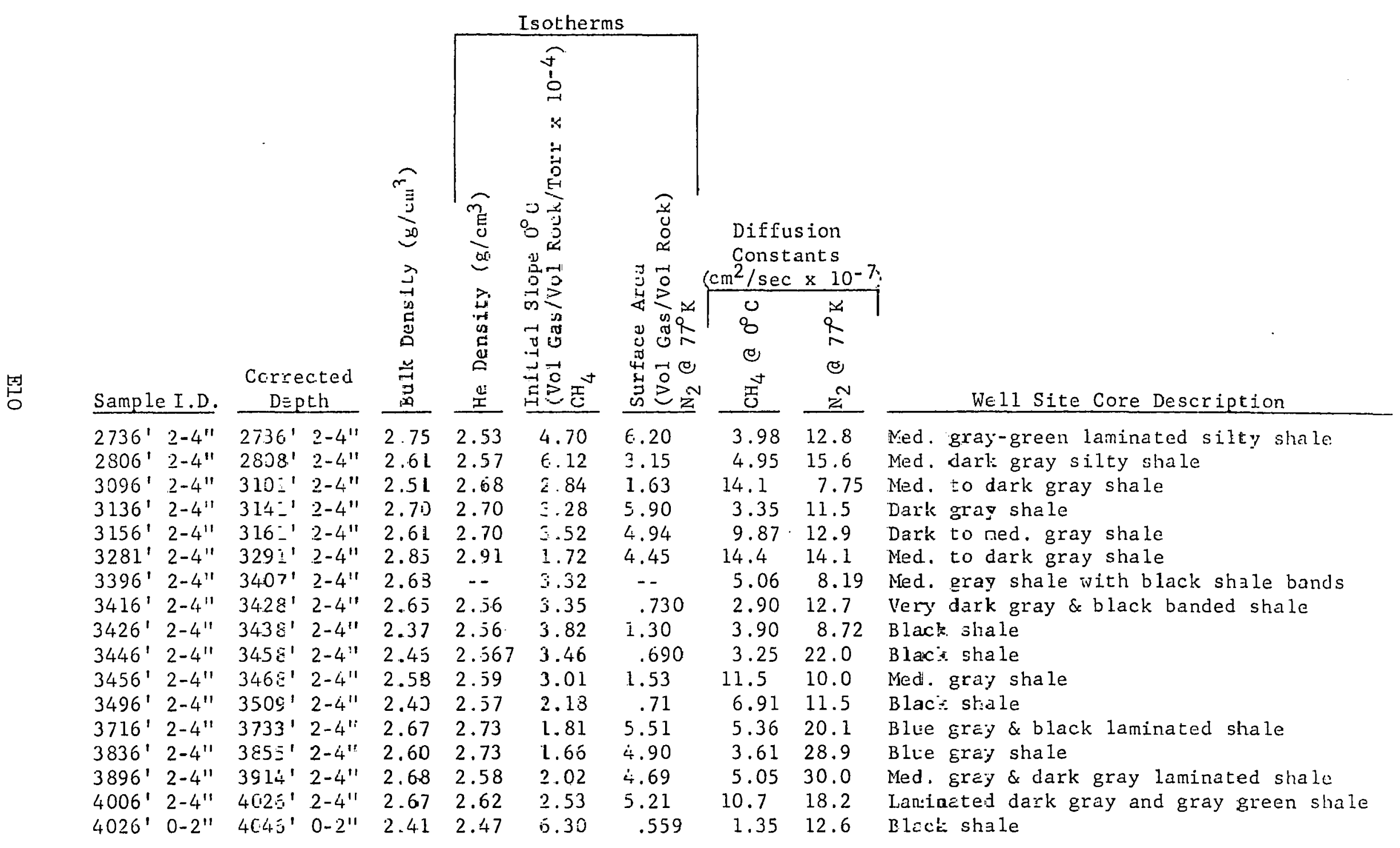


TABLE II. COMPARISON OF TYPE OF GRINDING

\begin{tabular}{|c|c|c|}
\hline & Ball ili: 1] & Percussion ilotili: \\
\hline Sample I.D. & $3446^{\prime} 2-4^{\prime \prime}$ & $3445^{\prime} \quad 2-4^{\prime \prime}$ \\
\hline Corrected Depth & $3458^{\prime} 2-4^{\prime \prime}$ & $3455^{\prime} \quad 2-4^{\prime \prime}$ \\
\hline Eulk Density $\left(\mathrm{g} / \mathrm{cm}^{3}\right)$ & 2.46 & 2.46 \\
\hline Isotherms-- & & \\
\hline He Density $\left(\mathrm{g} / \mathrm{cm}^{3}\right)$ & 2.47 & 2.67 \\
\hline $\begin{array}{l}\text { Initial Slope } 0^{\circ} \mathrm{C} \\
\left.\quad \text { (Vol Gas/Vol Rock/Torr } \times 10^{-4}\right) \quad \mathrm{CH}_{4} \\
\text { Surface Area (Vol gas/Vol Rock) }\end{array}$ & $\begin{array}{l}3.31 \\
1.40\end{array}$ & 3.46 \\
\hline Diffusion Constants $\left(\mathrm{cm}^{2} / \mathrm{sec} \times 10^{-7}\right)--$ & 1.40 & \\
\hline $\begin{array}{l}\mathrm{CH}_{4} \text { @ } 0^{\circ} \mathrm{C} \\
\mathrm{N}_{2} \text { a } 77^{\circ} \mathrm{K}\end{array}$ & $\begin{array}{l}2.59 \\
6.91\end{array}$ & $\begin{array}{l}3.25 \\
22.0\end{array}$ \\
\hline Wel1 Site Core Description & Black shale & Black shale \\
\hline
\end{tabular}

TABLE III. DIFFUSION OF $\mathrm{CH}_{4}$ IN SLABS AT $0^{\circ} \mathrm{C}$

\begin{tabular}{|c|c|c|c|c|}
\hline Sample I.D. & $\begin{array}{c}\text { Corrected } \\
\text { Depth }\end{array}$ & $\begin{array}{l}\text { Diffusion Constant } \\
\left(\mathrm{cm}^{2} / \mathrm{sec} \times 10^{-7}\right)\end{array}$ & $\begin{array}{l}\text { Well Site Core } \\
\text { Description }\end{array}$ & $\begin{array}{l}\text { Slab Surface } \\
\text { Description }\end{array}$ \\
\hline $27.36^{\prime} 2-4^{\prime \prime}$ & $2736^{\prime} 2-4^{\prime \prime}$ & 12.5 & $\begin{array}{l}\text { Med. gray-green } \\
\text { laminated silty shale }\end{array}$ & Dull \\
\hline $3426^{\prime} 2-4^{\prime \prime}$ & $3438^{\prime} 2-4^{\prime \prime}$ & .589 & Black shale & Shiny \\
\hline $3836^{\prime} 2-4^{\prime \prime}$ & $3855^{\prime} 2-4^{\prime \prime}$ & 22.0 & Blue gray shale & Dul1 \\
\hline
\end{tabular}

TABLE IV. OUTGASSING RESULTS, Volume of Gas Per Unit Volume of Rock

\begin{tabular}{|c|c|c|c|c|c|c|}
\hline Sample I.D. & $\mathrm{V}_{\mathrm{CH}_{4}}$ & $\mathrm{C}_{2} \mathrm{H}_{6}$ & $\mathrm{~V}_{3} \mathrm{H}_{8}$ & $\mathrm{~V}_{\mathrm{CO}_{2}}$ & $\mathrm{~V}_{2}$ & $\mathrm{~V}_{\mathrm{N}_{2}}$ \\
\hline $2736^{\prime} 2-4^{\prime \prime}$ & .028 & 0 & 0 & 0 & -.06 & .08 \\
\hline $2806^{\prime} 2-4^{\prime \prime}$ & 0 & 0 & 0 & 0 & -.06 & .07 \\
\hline $3096^{\prime} 2-4^{\prime \prime}$ & .127 & .04 & 0 & 0 & -.135 & -.03 \\
\hline $3136^{\prime} 2-4^{\prime \prime}$ & .09 & .03 & 0 & 0 & -.09 & .02 \\
\hline $3156^{\prime} 2-4^{\prime \prime}$ & .08 & .04 & 0 & 0 & -.1 & 0 \\
\hline $3281^{\prime} 2-4^{\prime \prime}$ & .06 & .02 & 0 & 0 & -.05 & .05 \\
\hline $3396^{\prime} 2-4^{\prime \prime}$ & .200 & .05 & .02 & 0 & -.15 & -.11 \\
\hline $3416^{\prime} 2-4^{\prime \prime}$ & .740 & .246 & .154 & .157 & -.473 & -.53 \\
\hline $3476^{\prime} 2-4^{\prime \prime}$ & 565 & .215 & .139 & 0 & -.26 & -.65 \\
\hline $3446^{\prime} 2-4^{\prime \prime}$ & .704 & .242 & .158 & 0 & -.29 & -.54 \\
\hline $3456^{\prime} 2-4^{\prime \prime}$ & .270 & .078 & .040 & 0 & -.14 & -.15 \\
\hline $3496^{\prime} 2-4^{\prime \prime}$ & .12 & .047 & .016 & 0 & -.072 & -.11 \\
\hline $3716^{\prime} 2-4^{\prime \prime}$ & .004 & 0 & 0 & 0 & -.04 & .02 \\
\hline $3836^{\prime} 2-4^{\prime \prime}$ & 0 & 0 & 0 & 0 & .005 & -.005 \\
\hline $3896^{\prime} 2-4^{\prime \prime}$ & .265 & .073 & .02 & 0 & -.12 & -.001 \\
\hline $4006^{\prime} 2-4^{\prime \prime}$ & .37 & .12 & .025 & 0 & -.24 & -.01 \\
\hline $4026^{\prime} 2-4^{\prime \prime}$ & 1.37 & .523 & .239 & 11 & -.30 & -.18 \\
\hline
\end{tabular}




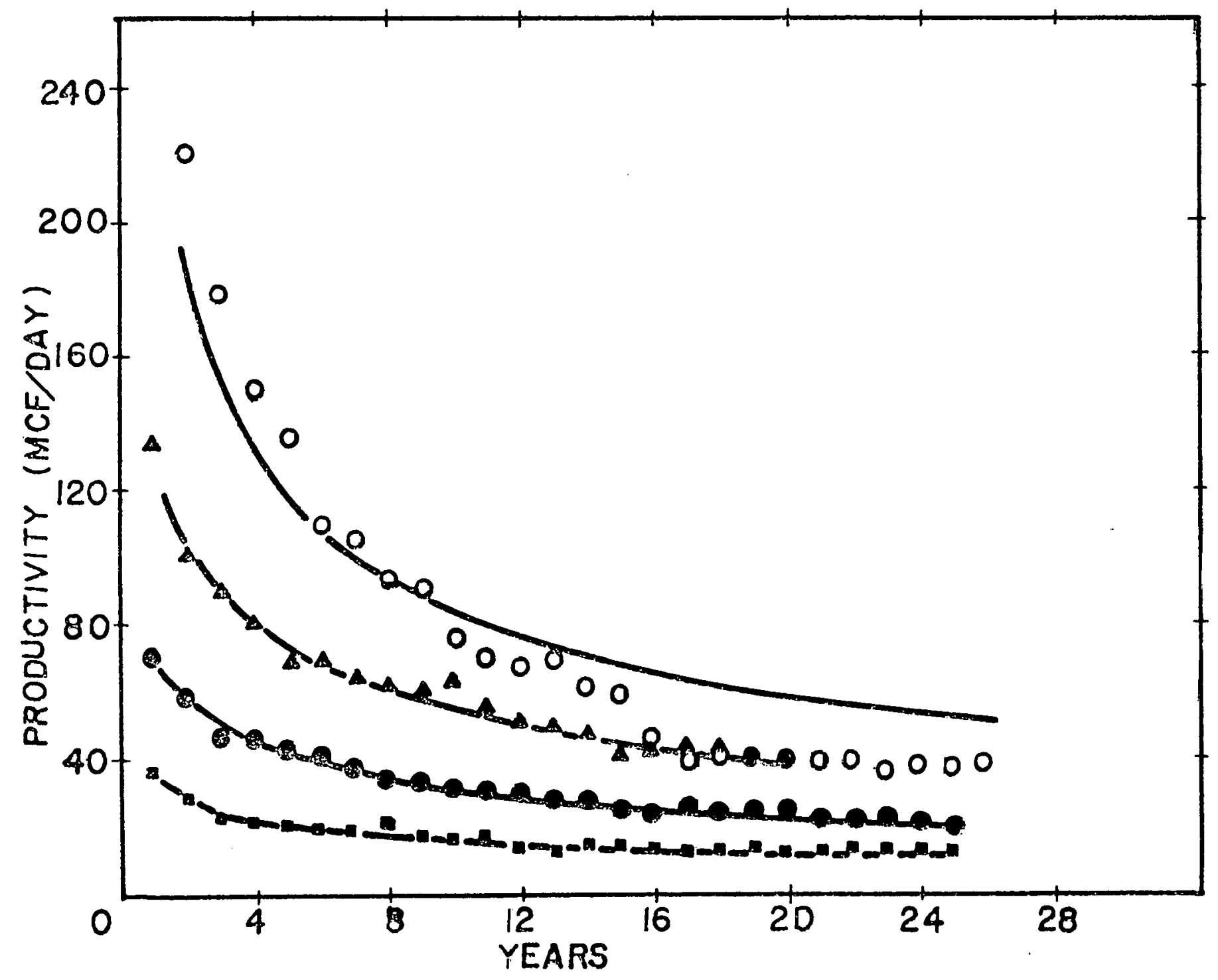

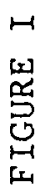




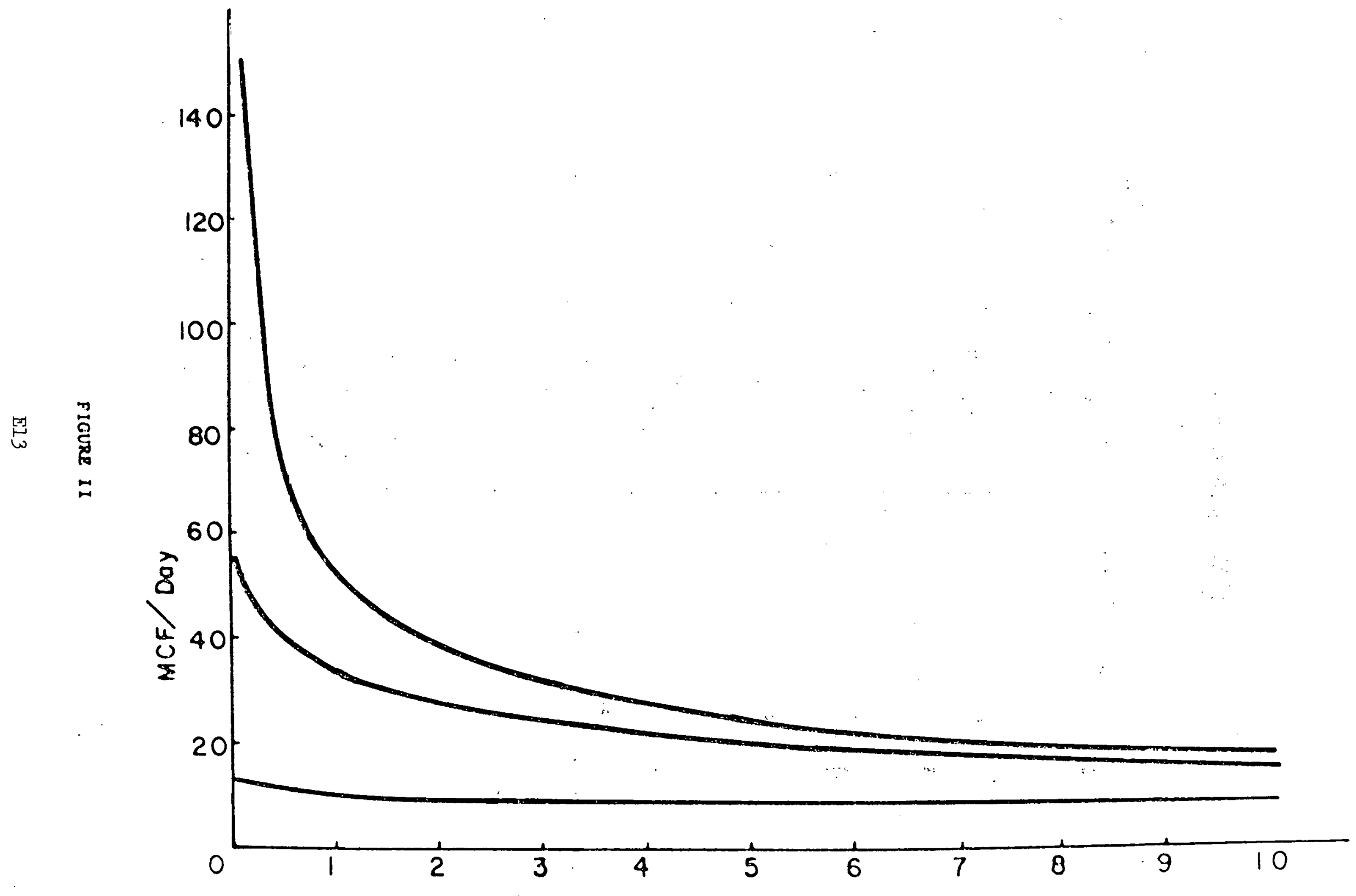




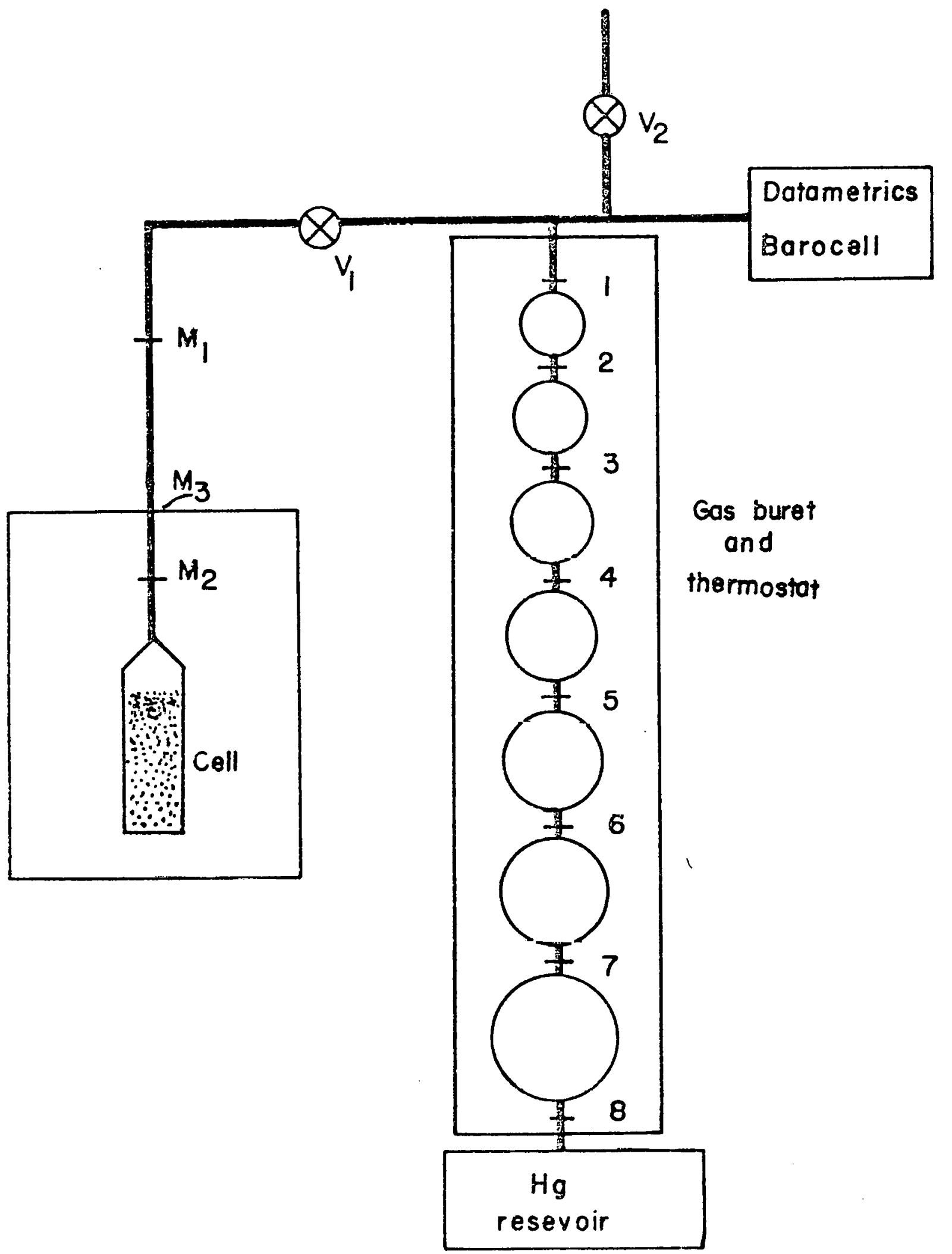

F IGURE II I 


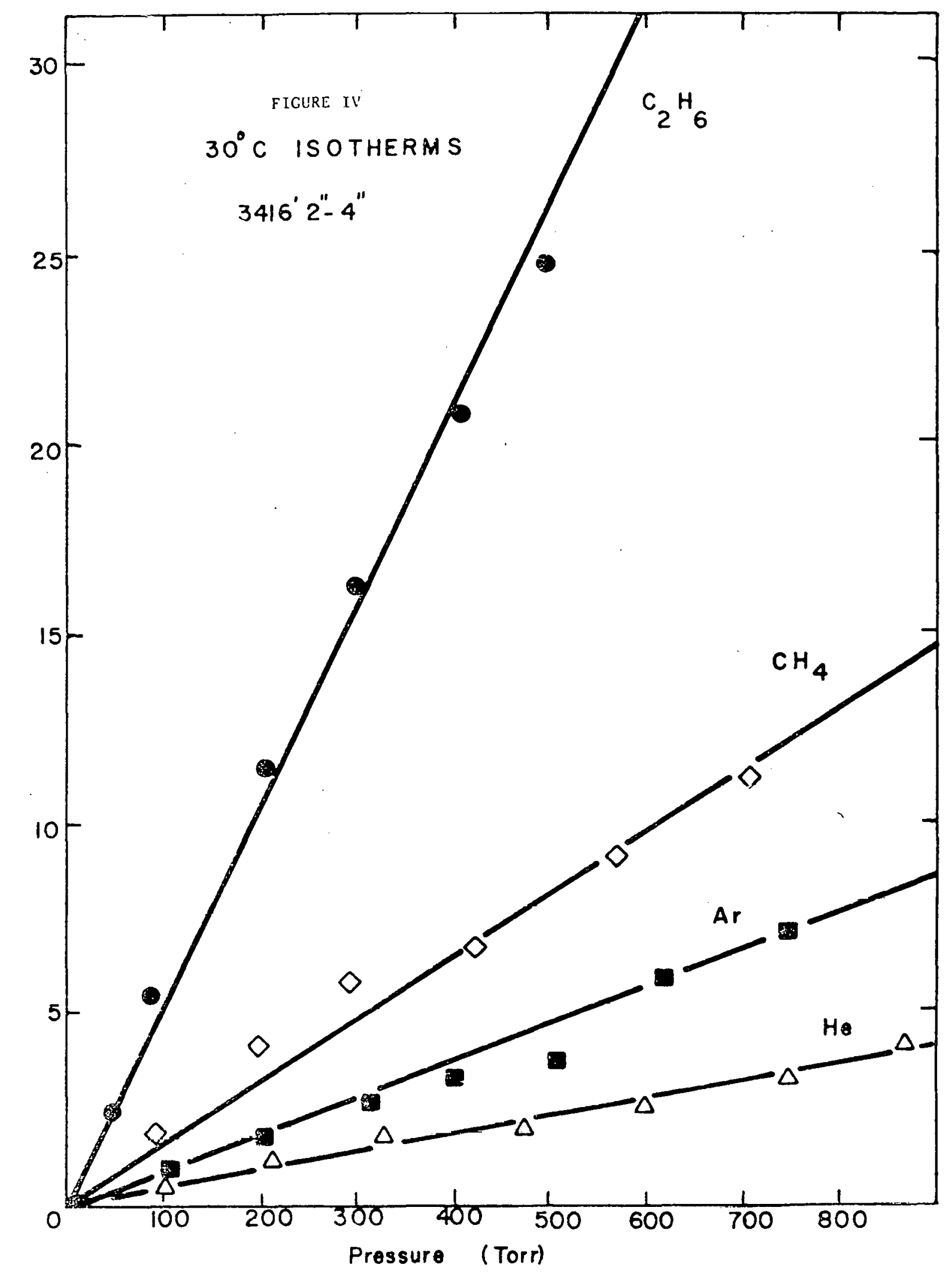


F. TRAVEL

1) Outgassing Workshop, $\mathbb{E} R C, 5$ May 1977, attended by Paul Schettler and Eric Jensen.

2) Fractography Workshop, 27-29 June 1977, Ramada Inn, Morgantown, attended by Paul Schettler.

G. FINANCIAL DATA

This function is being handled by separate report from our Accounting Office. 